\title{
SUBSTANTIVE DUE PROCESS: THE EXTENT OF PUBLIC EMPLOYEES' PROTECTION FROM ARBITRARY DISMISSAL
}

\section{INTRODUCTION}

One may not have a constitutional right to go to Baghdad, but the Government may not prohibit one from going there unless by means consonant with due process of law. ${ }^{1}$

The nature and extent of the substantive due process rights of public employees are presently very obscure. When a government employment rule does not touch on an employee's protected constitutional rights, it is not certain to what extent the courts are willing to circumscribe the state's traditional power to compel employee adherence to rules on threat of dismissal. Despite the absence of independent claims under the first, fifth, or other amendments, are there circumstances in which a state's rule will be struck down purely on grounds of substantive due process because it is arbitrary, irrational, or unreasonable? For example, could a rule which conditioned discharges on homosexuality, default on debts, an arrest record, public intoxication, or fornication with one's fiance(e) be successfully attacked? The government wishes to ensure efficient, nondisrupted service to the public, and it needs the power to dismiss an employee who is lazy, inefficient, insubordinate, or incompetent. The individual employee, on the other hand, has both a liberty interest ${ }^{2}$ and a property inter$\mathrm{est}^{3}$ in keeping his or her employment, and an interest in exercising other rights protected by the Constitution. ${ }^{4}$

' Cafeteria \& Restaurant Workers Local 473 v. McElroy, 367 U.S. 886, 894 (196I) (quoting Homer v. Richmond, 292 F.2d 719, 722 (D.C. Cir. 1961)) (emphasis added).

${ }^{2}$ Board of Regents v. Roth, 408 U.S. 564 (1972) (liberty encompassed an employee's interest in his good name and integrity and in avoiding the stigma of discharge with concomitant diminution of future job prospects); Hostrop v. Board of Junior College Dist. No. 515, 47 I F.2d 488 (7th Cir. 1972) (loss of job deemed a "liberty" interest).

${ }^{3}$ Bell v. Burson, 402 U.S. 535, 539 (1971) ("Once licenses are issued . . . their continued possession may become essential in the pursuit of a livelihood. Suspension of issued licenses thus involves state action that adjudicates important interests of the licensees."); Hostrop v. Board of Junior College Dist. No. 515, 471 F.2d 488 (7th Cir. 1972) (loss of job deemed a "property" interest).

E.g., Pickering v. Board of Educ., 391 U.S. 563 (1968) (freedom of speech); Keyishian v. Board of Regents, 385 U.S. 589 (1967) (loyalty oath violative of first amendment rights); Slochower v. Board of Higher Educ., 350 U.S. 551 (1956) (freedom against coerced self-incrimination). 
Once a deprivation of a constitutionally protected interest has been shown, the state's and the employee's interests must be balanced. ${ }^{5}$ The case law evidences a gradual development of how this balance is to be struck under a diverse set of factual situations, yet recent pronouncements by the courts leave the issues unresolved in many important respects. New and difficult questions have been raised and not yet answered; judicial analysis has been sparse and unconvincing.

This Comment will attempt to show that, on the basis of recent Supreme Court and court of appeals precedent, a strong argument can be made for the existence under the due process clause of protection from arbitrary government dismissal, independent of any other right granted by the Constitution. The Supreme Court opinion in Cleveland Board of Education $v$. LaFleur ${ }^{6}$ hints at the existence of such a right. A recent case in the Fifth Circuit appears to proceed under the assumption that it exists. ${ }^{7}$

Accepting arguendo that such substantive due process rights do exist, there is a pressing need to delineate the contours of the doctrine. The stakes in the resolution of these issues are enormous. ${ }^{8}$ The efficient and vigorous administrator requires proper judicial buoys to demark a safe course for an agency's dismissal rules. To maintain effective public service, the agency must preserve considerable latitude to dismiss incompetent employees. The public employee needs clear and well-defined protection against arbitrary dismissal, protection that does not now exist. He or she needs to be able to identify and challenge arbitrary dismissal rules.

The balance between the government's interest in efficiency and the public employee's interest in avoiding arbitrary dismissal must be struck by referring to several factors, including the nature of the job, the alleged cause for the discharge, and the nature of the state's interest in enforcing its rules. The role of these factors in defining a substantive due process doctrine of government dismissal is the focus of the Comment's concluding section.

\section{LaFleur: Hints of a Substantive Due Process Right} Forbidding Arbitrary Government Dismissal

Thus far; the Court has not had to decide whether the doctrine of substantive due process has any independent im-

${ }^{5}$ Cafeteria \& Restaurant Workers Local 473 v. McElroy, 367 U.S. 886, 895-99 (1961); Lipp v. Board of Educ., 470 F.2d 802 (7th Cir. 1972).

6414 U.S. 632 (1974).

${ }^{7}$ Thompson v. Gallagher, 489 F.2d 443 (5th Cir. 1973).

${ }^{8}$ There are about 13.1 million public employees in the United States. R. Smith, 
port in the area of government dismissals. Most government dismissal cases either have concerned a right guaranteed by the Constitution outside of the due process clauses ${ }^{9}$ or have emerged from an inadequate procedural setting. ${ }^{10}$ Only when an unmistakable substantive claim of dismissal under an arbitrary rule is presented in an adequate procedural setting will the Court be forced to confront the issue. The markings left

H. Edwards, \& R. Clark, Labor Relations Law in the Public Sector 5 (1974).

${ }^{9}$ See note 4 supra.

10 Unlike its relative, substantive due process, the doctrine of procedural due process has recently undergone substantial development in dismissal cases. It has been held that procedural due process must be accorded to a nonprobationary employee. Perry v. Sindermann, 408 U.S. 593 (1972); Board of Regents v. Roth, 408 U.S. 564 (1972). Beyond the probationary period the employee acquired a protected "property" interest in his continued employ. In many cases probation is a formal stage; where it is not, a de facto "expectation" of continued employment triggers the due process guarantees. Perry v. Sindermann, supra; Connell v. Higginbotham, 403 U.S. 207 (1971). The nature of the process which is procedurally due a permanent employee upon discharge is not altogether settled. At the least, a hearing procedure must be afforded. Perry v. Sindermann, supra.

Constitutional arguments regarding requirements of specific protections for employees are often avoided, because a multitude of state and federal statutes and regulations provide substantial recourse against arbitrary action by government. Federal law provides for discharge of civil service employees "only for such cause as will promote the efficiency of the Service," 5 U.S.C. \$ 7501(a) (1970); agencies promulgate more particularized regulations regarding suspensions and removals. Executive Order No. 10987, 3 C.F.R. 519 (1959-1963 Comp.), establishes guidelines for appeals of administrative decisions; 5 U.S.C. $\$ 702$ (1970) provides for judicial review.

Title VII of the Givil Rights Act of 1964, 42 U.S.C. $\$ \S 2000 \mathrm{e}$ to $2000 \mathrm{e}-15$ (1970), was amended in the Equal Employment Act of 1972, 42 U.S.C. $\$ \S 2000$ e(a)-(b) (Supp. II, 1972), to extend the jurisdiction of the Equal Employment Opportunity Commission to state employees. This confers substantial statutory protection to employees from arbitrary and discriminatory action based on "race, color, religion, sex, or national origin ... ." 42 U.S.C. $\$ 2000 \mathrm{e}-2$ (a) (1970).

Many states likewise have statutory protection for civil service employees. Illinois, for example, provides both procedural protections of notice of charges and a hearing, and requires a showing of cause which is detrimental to the service, satisfying at least minimal procedural and substantive due process. Ill. ANN. Stat. ch. 24, \& 10-1-18 (Smith-Hurd Supp. 1973).

Thus, by a patchwork of federal and state provisions, arbitrary dismissal of government employees has been limited. The need for constitutional adjudication has been largely obviated. But see Arnett v. Kennedy, 94 S. Ct. 1633 (1974).

In addition to statutory and judicial protection, state employees have been protected from arbitrary state action by union contracts negotiated with government employers, e.g., Lipp v. Board of Educ., 470 F.2d 802 (7th Cir. 1972); Embrey v. Hampton, 470 F.2d 146 (4th Cir. 1972).

Disclosure of the grounds of discharge, together with an opportunity to rebut or "challenge their sufficiency" must also be available. Perry v. Sindermann, 408 U.S. 593 (1973).

Other requirements of procedural due process as it has been defined in the criminal justice system have not thus far been applied to the public employment field by the Supreme Court. The Court has given some indication that it does not consider dismissal from government employ to be analogous to defending oneself in criminal and civil trials. Pickering v. Board of Educ., 391 U.S. 563, 574 (1968). 
by LaFleur suggest that such a claim may be valid under the Constitution.

In LaFleur the Supreme Court invalidated regulations mandating leave without pay for teachers reaching their fifth month of pregnancy and prohibiting their return to work for at least three months after childbirth. The Court's opinion avoided the equal protection arguments which had been urged upon it by the parties and resolved the question solely on due process grounds. ${ }^{11}$ Initially the Court found that the Board's regulation, by "penaliz[ing] the pregnant teacher for deciding to bear a child, . . . can constitute a heavy burden on the exercise of ... protected freedoms." 12 The valid state interests the Board allegedly furthered by its rule were the assurance of continuity in the education of its children and the desired administrative conveniences of ample notice of departure and of a per se rule rendering individualized hearings unnecessary. The Court structured its examination in terms of "whether the interests advanced in support of the rules . . can justify the particular procedures [the Board has] adopted" or whether the rules "needlessly, arbitrarily, or capriciously impinge upon this vital area of a teacher's constitutional liberty." 13 The procedures were found to employ an irrebuttable presumption of incompetency "not necessarily or universally true in fact"; furthermore, the Court found that "the State has reasonable alternative means of making the crucial determination."14 The Court concluded that the due process clause requires "a more individualized determination." 15

Without more, this clearly implies that an aggrieved employee is only entitled to freedom from arbitrary procedures when a substantive right defined elsewhere in the Constitution is threatened. However, the Court went well beyond what was required by the nature of the case as it had just been defined.

11414 U.S. 632, 651 (1974). See id. at 651-52 (Powell, J., concurring in the result, but adopting an equal protection approach). The parallelism of the due process and equal protection arguments in such cases is striking. For an interesting contrast, compare LaFleur with Green v. Waterford Bd. of Educ., 473 F.2d 629 (2d Cir. 1973) (equal protection). Identical issues and considerations were raised with substantially similar resolution in the two cases, but LaFleur was decided on due process grounds while Green was decided on an equal protection rationale. The Supreme Court acknowledged the equivalence of the two formulations in some circumstances in Bolling v. Sharpe, 347 U.S. 497, 499 (1954).

12414 U.S. at 640 . The protected freedoms mentioned by the Court included "freedom of personal choice in matters of marriage and family life," id. at 639, and the "right "to be free from unwarranted governmental intrusion into matters so fundamentally affecting a person as the decision whether to bear or beget a child," id. at 640 (quoting Eisenstadt v. Baird, 405 U.S. 438, 453 (1972)).

${ }^{13} \mathrm{Id}$.

${ }^{14} I d$. at $644-45$ (quoting Vlandis v. Kline, 412 U.S. 441,452 (1973)).

${ }^{15} \mathrm{Id}$. at 645 . 
It found that the arbitrary departure dates for pregnant teachers had no rational relationship to the state interest of preserving continuity of instruction. ${ }^{16}$ The Cleveland return to work regulation, requiring a three-month wait after childbirth, was described as "wholly arbitrary and irrational . . . . [It] serves no legitimate interest, and unnecessarily penalizes the female teacher for asserting her right to bear children." 17 This language deals with the substantive rationality of the pregnancy rule itself as an independent matter.

This willingness by the Court to give substantive import to the due process clause in government dismissal cases is further signalled by its decision in Arnett $v$. Kennedy. ${ }^{18}$ There the appellee, an employee of the Office of Economic Opportunity, had been dismissed for claiming that two supervisors had attempted to bribe other employees with community action grants in order to obtain statements impugning the appellee and others. The three judge district court ${ }^{19}$ held that the LloydLaFollette $\mathrm{Act}^{20}$ and its attendant civil service and OEO regulations" "denied appellee due process of law because they failed to provide for a trial-type hearing before an impartial agency official prior to removal; the court also held the Act and implementing regulations unconstitutionally vague because they failed to furnish sufficiently precise guidelines as to what kind of speech may be made the basis of removal action."22 The Supreme Court reversed, with five Justices agreeing that no pre-dismissal hearing by an impartial official was required. Six Justices supported the result on the ground that the statute was drawn narrowly enough. There was no majority opinion.

Amett is interesting in the substantive due process context because a majority of the Justices rejected the view of Justice Rehnquist that the "substantive right" of expectancy of continued employment was conditioned upon the procedural safeguards established legislatively to protect those rights. ${ }^{23} \mathrm{~A}$ majority thus agreed that the failure of the Lloyd-LaFollette Act to provide for a pre-dismissal hearing by an impartial agency official did not effectively limit any legitimate expectation the appellee might have had.

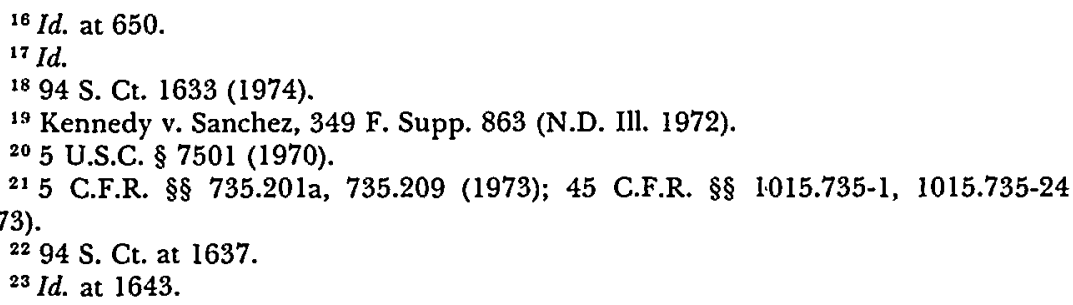


LaFleur and Arnett indicate that a substantive due process right forbidding arbitrary dismissal may exist and is likely to be defined independently of the procedural safeguards that surround it. Is a regulation that is "wholly arbitrary and irrational," as promulgated or as applied, valid under a substantive due process test in a case involving no specially protected interest? In the recent case of Thompson $v$. Gallagher, ${ }^{24}$ the Fifth Circuit reached the conclusion that it is not. The appellant, a custodian at a diesel plant, challenged a city regulation under which he had been dismissed for having received an undesirable, but not dishonorable, discharge from the United States Army. The regulation was attacked as violative of the due process and equal protection clauses. Although finding no affirmative constitutional right of public employment for those less than honorably discharged, the court read the fourteenth amendment as "a general prohibition against arbitrary and unreasonable government action." 25

Writing for the court, Judge Morgan found that the appellant's right to be sheltered from arbitrary government action entitled him to reinstatement, despite the absence of a controversy over a constitutionally protected interest independent of the fourteenth amendment. Although previous public employee dismissal cases all involved such independent rights, the court reasoned, "[j]ust as a public employee does not give up his First Amendment rights when he begins receiving a pay check from the government, neither does he give up his right to due process of law." 26 On substantive grounds the court was willing to ask whether the regulation in question was a "rational means of advancing a valid state interest." 27

The court rejected as invalid on its face any interest the city had in a per se rule barring employment to veterans, with undesirable discharges. It demanded to know "what [it is] about a person with other than an honorable discharge that makes him unfit to be a city employee." ${ }^{28}$ An inference by the city of either criminality or antisocial behavior was found impermissible. $^{29}$ In the future the city would have to specify which facets of the military discharge were relevant to the petitioner's duties as custodian. In addition, in apparent dictum, the panel noted that the city's case would be helped by a finding of a "comprehensive scheme which enumerated char-

24489 F.2d 443 (5th Cir. 1973).

${ }^{25} \mathrm{Id}$. at 446 .

${ }^{26} I d$. at 447.

${ }^{27} I d$.

${ }^{28}$ Id. at 448 .

${ }^{29} I d$. at 448,449 . 
acteristics deemed to be conducive to competent performance as a city employee . . .." Noting that other than honorable discharges may be granted for a wide variety of "antisocial" characteristics, including "security considerations, sodomy, homosexuality, financial irresponsibility and bed-wetting," 31 the court found the regulation "too broad to be called "reasonable" "and stated that the lack of individualized consideration made the regulation "irrational." 32

Thompson goes further than LaFleur, then, by subjecting a dismissal rule to substantive due process analysis for arbitrariness, regardless of the absence of protected rights found elsewhere in the Constitution. Under Thompson, a public employee cannot be dismissed for failure to meet an employment requirement unless the government determines in a procedurally fair manner both that the employee did in fact fail to meet the condition and that the condition furthered a legitimate interest in guaranteeing good service, which would be adversely affected without it.

Thompson thus sets the stage for judicial articulation of how the balance of the state interest in efficiency is to be struck against the need to protect the public employee against bureaucratic whim and arbitrariness. The concluding section of the Comment will attempt to specify some of the factors that should be considered in such balancing.

\section{Beyond LaFleur: Developing a Coherent Substantive Due Process Doctrine for Government Dismissals: ARBITRARINESS VERSUS EFFICIENCY}

If the courts are to define the substantive due process doctrine more adequately than they have to date, they will have to make their rules with little guidance from precedent. It can be asserted with confidence, on the basis of LaFleur ${ }^{33}$ and other cases, ${ }^{34}$ that to pass constitutional muster a discharge cannot infringe unduly upon the "family interest" or upon first and fifth amendment rights. Uncertainty easily arises, however-for example, at what point does criticism of superiors and working conditions step out of protection of the first amendment and become merely insubordination? Presumably all grounds for discharge must relate in some fashion to more effective government services. It is the quantum of substantive

\footnotetext{
${ }^{30}$ Id. at 449 .

${ }^{31} I d$.

${ }^{32} I d$.

${ }^{33}$ See text accompanying notes 11-17 supra.

${ }^{34}$ See note 4 supra.
} 
due process, the degree of relationship required, that is yet to be developed and explored.

The relevant factors for defining any independent protection by the due process clause against mere arbitrariness or capriciousness should include the particular job held, the ground for discharge, the interests the government declares impaired by continued employ, and the strength of the inference of impairment from the cause upon which the discharge is based.

\section{A. The Job}

The particular job the employee holds is an important variable in assessing the merit of his due process claim. Each job will have its own set of legitimate, work-related causes for dismissal. Thus, a regulation of questionable relevance to one job may be important to another.

What characteristics of different jobs might allow different regulations? A greater degree of exposure to the public and greater levels of esteem and investment of public confidence in a position may sustain a more stringent general "good character" requirement-a high school principal might constitutionally be subject to dismissal for behavior that is acceptable from someone such as the school's janitor, whose job has less visibility. A job conferred on an individual by a state may also carry with it a sensitivity to public opinion based upon its symbolic status. Teachers and policemen, who fill roles viewed by the community as models for good behavior, might thus be subject to greater state-imposed restraints than people whose jobs are less highly regarded.

The same behavior by public employees with different jobs might also lead to different constitutional results on the basis of permissible inferences regarding effects on government service. For example, a custodian's or social worker's inability to handle his or her personal financial affairs properly might not be grave enough to warrant discharge where no direct job performance was affected; but the same conduct by an agent with fiscal responsibility could lead to a substantial loss of public confidence and to a judicial determination that a discharge for this reason was constitutional.

\section{B. The Cause of the Discharge}

Some grounds for dismissal, such as incompetence or insubordination, are unquestionably permissible ones. Others, such as overt racial or sexual discrimination, are equally impermissible. Where there is no showing of relation to job perfor- 
mance, discharges made in response to the exercise of a protected constitutional right are also impermissible. In Pickering $v$. Board of Education, ${ }^{35}$ a teacher spoke out publicly against the spending practices of the local school board; principles of freedom of speech were held to protect him against discharge. Although the Court recognized that the state's interest in regulating the speech of its employees was greater than its interest vis-à-vis the general public, it held that the teacher had spoken out in his capacity as citizen, not in his capacity as employee. The Court noted that Pickering's statements were not concerned with persons with whom he had daily contact, that no questions were presented regarding discipline or harmony among co-workers, and that his employment relationship to those he criticized did not require loyalty or confidence in order to function efficiently. ${ }^{36}$ Furthermore, the Court found that Pickering's position did not give him greater ability either to speak to or to have an impact upon the public. Finally, the Court found that Pickering's speech could be neither shown nor presumed "to have in any way either impeded [the] proper performance of his daily duties in the classroom or to have interfered with the regular operation of the schools generally." ${ }^{37}$ The implication was that, even in the case of exercise of freedom of speech, a different result might have obtained had any of the noted effects been present.

Among the other reasons for dismissal that the courts do not link to protected interests, such as arrest, indebtedness, sexual impropriety, and other than honorable discharges, some seem greater "cause" for dismissal than others. Thus, the more adverse the impact is upon the performance of the job and provision of the governmental service, the better the case for dismissal is. Where the facts show only a marginal impact upon performance, Pickering may require a court to conclude that the state's interest in discharge for the particular cause alleged is arbitrary and violative of substantive due process despite the absence of a protected interest.

The proper balancing of the interests of the state and the employee, even when the impact upon job performance can be assessed with accuracy, is nonetheless very difficult. Is arrest or indictment sufficient cause for discharge, or must the state wait until the employee is convicted? A discharge at the arrest stage may compromise the presumption of innocence. ${ }^{38} \mathrm{~A}$ con-

\footnotetext{
35391 U.S. 563 (1968).

${ }^{36}$ Id. at 570.

${ }^{37}$ Id. at 572-73 (footnote omitted).

${ }^{38}$ Embrey v. Hampton, 470 F.2d 146, 147 (4th Gir. 1972).
} 
viction probably permits a stronger inference of unfitness or bad character. On the other hand, when combined with the normal criminal penalty a discharge may represent a sanction more severe than that desired by the legislature when it decided how to punish people who committed specific crimes.

As another example, discrete sexual activities and preferences are demonstrably less the business of the state than matters which come to public notice. Purely personal matters would thus be distinguished from public sexual solicitations and from indebtedness which becomes part of the public record when it is reduced to judgment. Nonetheless, the courts have not developed coherent principles for determining which sorts of public and private behavior are sufficient grounds for discharge and which are not. ${ }^{39}$ In any event, the power of the state, acting as an employer, to intrude into sensitive personal areas should be narrowly circumscribed. ${ }^{40}$

\section{The State's Interest}

In support of its decision to dismiss an employee, the state can assert a variety of interests which it hopes to promote and a substantial number of adverse effects on the public service which it hopes to avert. Unless the courts can infer a logical relation between the rules for dismissal and the performance of the job by the dismissed employee, these putative state interests will increasingly be attacked successfully.

Beyond the state's obvious interest in avoiding demonstrable interference by the employee with satisfactory performance of the government's functions, there are three categories of state interests which have been forwarded in justification of employee dismissals. The first concerns the need to maintain the morale of fellow employees; the second, the need for low-risk employees of good character; and the third, the public image of the agency.

${ }^{39}$ See Norton v. Macy, 417 F.2d 1161 (D.C. Cir. 1969) (arrest for homosexual solicitation insufficient ground for discharge); Carter v. United States, 407 F.2d 1238 (D.C. Cir. 1968) (single overnight stay with female may constitute sufficient cause for discharge); Taylor v. United States Civil Service Comm'n, 374 F.2d 466 (9th Cir. 1967) (two arrests for "vagrancy-lewd" sufficient grounds for discharge); White v. Bloomberg, 345 F. Supp. 133 (D. Md. 1972) (single debt insufficient ground for discharge; privacy argument not reached); Mindel v. United States Civil Service Comm'n, 312 F. Supp. 485 (N.D. Cal. 1970) (private cohabitation insufficient ground for discharge).

Drunkenness is another action which could conceivably be grounds for discharge if it were public, but would not be the state's concern if it were done privately. See, e.g., Nolting v. Civil Service Comm'n, 7 Ill. App. 2d 147, 129 N.E.2d 236 (1955).

${ }^{40}$ Cf. Roe v. Wade, 410 U.S. 113 (1973); Eisenstadt v. Baird, 405 U.S. 438 (1972); Stanley v. Georgia, 394 U.S. 557 (1969); Griswold v. Connecticut, 381 U.S. 479 (1965). 
1. Preserving Morale and an Effective Working Atmosphere

As one of its reasons for holding in Pickering $v$. Board of Education $^{41}$ that a teacher's public statement critical of the school administration did not constitute legitimate grounds for dismissal, the Supreme Court stated that no adverse effects had resulted from the statement with regard to the teacher's performance or his working relations with his colleagues and superiors. The Court thus implied that the discharge would have been permissible had these effects been present. What is left unclear by the Court's opinion is the question whether an employee can successfully challenge the state's interest in promoting group spirit.

This interest appears most clearly when interaction among employees is great or when group work is essential. In certain jobs this is very important. The police, for example, have traditionally enjoyed a quasi-military aura, and rely heavily on police force discipline. This is mandated by the nature of their work and their need for interdependence in difficult-and often dangerous-situations. An officer who is not trusted by his fellow officers is in some real sense counterproductive to the police force ${ }^{42}$ When circumstances warrant, the state must be free to rid itself of persons who are troublesome, captious, or not trusted by their peers.

Where, however, such interests are less clearly of value to a job, a court should give less weight to the state's concern. Not all jobs require the degree of skillful interaction among team members that the police and fire departments do. The power to dismiss persons because of failure to "get along" with their peers is inherently susceptible of abuse, and the criteria of Pickering should be generally accepted. The state should be required to show two things that it did not show in Pickering: that the job requires that the persons involved work well together with loyalty and mutual confidence, ${ }^{43}$ and that as a result of the proscribed activity relations between those to whom these bonds were important actually deteriorated. This twofold requirement would help protect public employees who hold unpopular views or behave in an unorthodox fashion from arbitrary discharge through use of agency regulations.

41391 U.S. 563 (1968).

$42 \mathrm{~J}$. Rubinstein, City Police (1973). This is also true in fire departments and hospitals, to name two outstanding examples. It is noteworthy that employees in all these jobs must function well in emergencies.

${ }^{43}$ The ability to work together with loyalty and mutual confidence was found to be inessential to the satisfactory performance of either the teacher or the members of the school board in Pickering. 


\section{The Need for Low-Risk Employees of Good Character}

A second type of state interest urged when a discharge is challenged is the governmental interest in employing persons of good character. In Thompson $v$. Gallagher ${ }^{44}$ the court strongly endorsed this interest. Yet it is not at all obvious that a legitimate interest in good character is distinguishable from an illegitimate interest in matters which do not concern job performance whatsoever, and which may intrude impermissibly into matters that should not concern the state.

Its employees' good character, if defined as their honesty or probity, is of reasonable concern to a state agency. But whether an employee goes to church, mows his lawn seasonably, pays child support promptly, or gives to the United Fund is not a legitimate concern of the state. These aspects of character are not relevant to employment by the agency. Character is too general a term. The particular dimensions of character that may be considered by the state in its decision to discharge should therefore be narrowly defined within legitimate limits; failures to meet specific character criteria should be objectively documented, lest the courts acquiesce in overbroad and unchecked application of such regulations. ${ }^{45}$

In addition, the risk aspect of character is sometimes raised. It is argued that some employees may be more likely than others to commit certain offenses that are admittedly grounds for dismissal. Debt can be said to lead to temptation to succumb to bribery and other dishonesty; homosexuality has been considered an Achilles' tendon permitting blackmail, especially where sensitive materials were considered. ${ }^{46}$

This argument is insupportable as grounds for discharge. It is the quintessence of the "irrebutable presumption" which is neither "necessarily [n]or universally true." 47 Additionally, like the pregnancy regulation in LaFleur, or the undesirable discharge provision attacked in Thompson, such a presumption as grounds for dismissal is grossly overinclusive in its effect when applied to all employees who fit the rule, and thus violative of due process. Termination of employment in such .cases is so unrelated to any legitimate state interest in avoiding dishonesty or disloyalty that it is arbitrary and irrational, and the state interest of "protection from an increased likelihood

44489 F.2d 443 (5th Cir. 1973). See text accompanying notes 24-32 supra.

45 Analogous to "character" in its vagueness is "conduct unbecoming an employee ...." Carter v. United States, 407 F.2d 1238, 1241 (D.C. Cir. 1968).

${ }^{46}$ But see Norton v. Macy, 417 F.2d 1161 (D.C. Cir. 1969) (homosexuality argument rejected by the court).

${ }^{47}$ Cleveland Bd. of Educ. v. LaFleur, 414 U.S. 632, 644 (1974) (quoting Vlandis v. Kline, 412 U.S. 441,452 (1973)). 
of dishonesty or disloyalty" is as illegitimate as an irrebuttable presumption. ${ }^{48}$

A somewhat similar situation exists when efficiency is affected by members of the public or persons involved with an employee (neighbors, estranged spouses, creditors) who phone his superiors to complain of his conduct, and thereby disturb the smooth operation of state offices. Here again, the balance must be struck delicately-a discharge might promote agency efficiency but not be directly related to employee conduct. The employee's control over the situation and an independent weighing of the privacy aspects of the employee's life against the antisocial character of the behavior complained of must be assessed. The court must, however, bear in mind that the employee is not directly responsible for the reduced efficiency of the agency. When the employee has no identifiable control over the complainant or the underlying behavior (or when he has control and is within his rights to do as he has), a discharge would be both arbitrary and irrational.

\section{The Government's Public Image}

A further category of interests advanced to justify dismissals is the potential or actual damage to the agency's public image that will result from retained employ of the individual. This is often phrased in terms of embarrassment, putting an agency in a bad light, or loss of public confidence. In LaFleur, the state's interest in avoiding the embarrassment of pregnant teachers in the classroom was not given serious attention by the Court:

[Evidence below indicates that] the rule had been adopted in part to save pregnant teachers from embarrassment at the hands of giggling schoolchildren .... [I]t was "not good for the school system" for students to view pregnant teachers ....

The school boards have not contended in this Court that these considerations can serve as a legitimate basis for a rule requiring pregnant women to leave work; we thus note the comments only to illustrate the possible role of outmoded taboos in the adoption of the rules. ${ }^{49}$

The attitude of the Court in LaFleur does not give comfort to those who would find an "embarrassing" employee

48 This could alternatively be analyzed in terms of an insufficient nexus to the legitimate interest of avoiding admittedly dishonest or disloyal people.

49414 U.S. at 641 n.9. 
deserving of discharge. Homosexuals, debtors, or those brought to court on matters unrelated to job conduct should be protected when there is no basis for their discharge other than the undesirable reflection their behavior or status has on the agency which employs them. Carrying the LaFleur analysis to these cases, a court would hold that a public agency's image should reside solely in its efficient, honest, and courteous service to the public.

The state unquestionably has legitimate interests at stake in the calibre of its employees and the quality of the public service. But substantive due process demands closer scrutiny of the precise interests allegedly impaired by an employee's continued employment. The more strongly and directly related the state's interest is to the performance of the service, the more legitimate it is. Discharge becomes far less supportable when the impairment becomes speculative, indirect, or merely cosmetic.

\section{The Nexus}

The final consideration in the development of a coherent substantive due process policy is how closely a given regulation must relate to an admittedly proper state purpose in order for discharges made under it to be valid. Two underlying issues must be resolved before a regulation can be held to be in compliance with the due process clause: it must not only be valid on its face, but it also must be valid as applied.

The first of these questions really is whether the regulation supports an inference that a given characteristic corresponds in most cases to shortcomings which the state may properly regard as ground for dismissal. For example, are debtors or those with other than honorable discharges unsatisfactory employees often enough to warrant a general conclusion to that effect and to sustain a regulation requiring such employees to be dismissed?

Once a court agrees that a given regulation is true in enough cases to sustain its validity on its face, the second question comes into play: which defenses must be available to an employee to break the presumption in his or her own case? This due process issue might be characterized as either substantive or procedural. Until recently, only this second question was considered to have any importance.

The recent decisions in Vlandis v. Kline $e^{50}$ and Bell v. Bur$\operatorname{son}^{51}$ focus more attention on the first question, however. 
Vlandis states that "permanent irrebutable presumptions have long been disfavored under the Due Process Clauses . . . ."52 Similarly, after citing Vlandis and finding the school board's pregnancy rule wholly arbitrary and irrational, the Court in Lafleur explained that it did not decide that a different cutoff date, closer to delivery, would be equally unreasonable, if buttressed by medical consensus of unfitness or reasonable and valid administrative concerns. In that event, the state would not have to provide an opportunity for challenge by individual employees.

The Court in LaFleur made no distinction between constitutionality "on a rule's face" and "as applied." Yet there is a difference between these concepts. Using the pregnancy case as an example, there is some rule, such as the five-month discharge in LaFleur, which is so arbitrary as to be violative of substantive due process on its face. Individualized hearings are irrelevant, for the premise is that five-month pregnant teachers are, on the average, as fit as any other sample of teachers. At some point in time, however, a presumption or inference of unfitness may justify a regulation, as long as provision is made for an individualized hearing into the circumstances of that case. The courts might find that, as medical consensus grows, a limited presumption, somewhat comparable to a probable cause for inquiry, is warranted.

Two major questions remain unexplored. The first is the quantity of consensus necessary to support a rule. Does due process require that fifty percent of a region's doctors say all pregnant women are unfit at a certain date, or that seventyfive percent say sixty-seven percent are?

The second question is the burden of proof at the hearing. It could be that upon challenge the employee would have to establish the inapplicability of the rule by reason of his individual fitness. Such a presumption of regularity of state action, with the consequent burden upon the employee, is consonant with traditional due process analysis. Alternatively, the state might have to demonstrate its basis for the regulation and give evidence to sustain its application in a given case. An example of this latter approach is found in Bell $v$. Burson. ${ }^{53}$ The Supreme Court there held that the State of Georgia had to make some preliminary showing of likely fault prior to revocation of a driver's license under its statute. In Vlandis $v$. Kline, ${ }^{\mathbf{5 4}}$

52412 U.S. at 446. See also Cleveland Bd. of Educ. v. LaFleur, 414 U.S. 632, 644-45 (1974); Stanley v. Illinois, 405 U.S. 645 (1972) (presumption that father of illegitimate children was unfit parent).

53402 U.S. 535 (1971).

54412 U.S. 441 (1973). 
on the other hand, Connecticut was required only to furnish a hearing to permit individuals to plead the affirmative defense that a presumption of out-of-state residency based on their address at the time of their application to the state university was not applicable to them. ${ }^{55}$ The difference might depend on a court's intuitive feeling that in one situation the state is more justified in making its link between cause and valid purpose than it is in the other.

The state has concerns of considerable moment in wishing to avoid lengthy hearings and difficult problems of proof. At a level of "reasonable relation" of a rule to a legitimate state interest, the rule should survive on its face, and simultaneously the burden should shift to the employee to show inapplicability, or arbitrariness of application. The "reasonable relation" should be satisfied at some point more compelling than "more likely than not," but could be constitutional at a point well short of "beyond a reasonable doubt." By eliminating all causes not reasonably related to valid state purposes, substantive due process would be satisfied. After this, the opportunity to put in an affirmative defense should be all that is required to satisfy a test of constitutionality "as applied."

Finally, on the continuum of relation to cause, the nexus between a stated cause and impaired employee functioning could grow so strong that a state could constitutionally apply a presumption irrebuttably. ${ }^{56}$ This is what LaFleur seems to imply in dicta. Examples might include rules that two weeks before projected delivery, all teachers must stop working; that a heroin addict may be discharged from the fire department; that an off-the-job child molester can be dismissed as a teacher; or that a person suffering a nervous breakdown can be removed from a demanding and delicate job, such as traffic controller at an airport or head of an agency.

\section{Conclusion}

The lower courts are just beginning to grapple with issues of dismissal from government jobs. The Pandora's box of substantive due process is just opening. Many constitutional norms have changed since Holmes' statement that " $[\mathrm{t}] \mathrm{he}$ petitioner may have a constitutional right to talk politics, but he has no constitutional right to be a policeman." 57

It is essential that substantive due process constraints on the state as employer be clarified. So doing would give guidance

\footnotetext{
${ }^{55} \mathrm{Id}$. at 452.

56 "Irrebuttably" in this context means that no individualized hearing or affirmative defenses would be allowed.

s7 McAuliffe v. Mayor, 155 Mass. 216, 220, 29 N.E. 517, 517 (1892).
} 
to those who administer government agencies so they can avoid arbitrariness, and simultaneously render the public adequate service. The degree to which we are all dependent on efficient government service and the state's legitimate interest in maintaining its capability to discharge unsatisfactory employees must be appreciated, as must the employee's legitimate interests. This Comment has attempted to identify the emergence of a substantive due process doctrine in this area and to suggest the factors that should be considered as this largely uncharted area of the law evolves. 